\title{
PENGARUH PENDIDIKAN LATIHAN (DIKLAT) KEPEMIMPINAN GURU DAN IKLIM KERJA TERHADAP KINERJA GURU Wildatun ulya 17002165
}

\author{
Email: wildaulya8399@gmail.com
}

\begin{abstract}
Abstrak
Pada umumnya organisasi pasti mengingin karyawan cakap dalam melaksanakan tugas guna mencapai tujuan organisasi. Maka dari pihak oranisasi dapat meningktkan kualitass kinerja karyawannya dengan melaksanakan pendidikan dan pelatihan. Tidak hanya itu lingkungan kerja yang nyaman,dan menyenagkan meruakan salah satu faktor yang mempengaruhi kinerja karyawan, maka dari itu pihak oraganisasi perlu menciptakan lingkungan kerja yang sesuai dan dan menyenangkan,sehingga dalam melaksnakan tugasnya karyawan senang. Tujuan dari penulisan artikel ini yaitu untuk mengungkapkan keterkaitan hubungan faktor pendidikan dan pelatihan kepemimpinan guru dan iklim kerja terhadap kinerja guru.
\end{abstract}

Kata kunci: kinerja guru,pendidikan dan pelatihan, dan iklim kerja

\section{Pendahuluan}

Pendidikan nasional diharapkan mampu mewujudkan manusia-manusia pembangunan yang dapat mebangun dirinya sendiri serta bersama-sama bertanggung jawab untuk membangun bangsa yang lebih baik lagi kedepannya.

Sekolah mempunyai tugas dan fungsi untuk melayani publik/ masyarakat, selain itu sekolah juga dipandang sebagai sebuah sistem sosial karena terdiri dari seperangkat elemen dan aktivitas yang salin berinteraksi antara yang satu dan yang lain membentuk intensitas sosial.

Indikator sumber daya manusia ditentukan oleh tingkat pendidikan masyarakatnya. Semakin tinggi kualitas sumber daya manusia ditentukan oleh tingkat pendidikan masyarakatnya begitu juga sebaliknya.

Keberhasilan pendidikan disekolah ditentukan oleh keberadaan gurunya baik itu dari wawasan keilmuan yang dimilki oleh guru itu, relevansi keilmuan guru dengan mata 
pelajaran yang diajarkan, pengalaman diklat yang pernah diikutinya serta iklim kerja dilingkungan sekolah yang bersangkutan..

Salah satu ciri krisis pendidikan di indonesia yaitu adalah guru belum mampu memperlihatkan kinerja yang memadai, maka dari itu perlu adanya upaya untuk meningktakan kinerja guru salah satu caranya yaitu dengan mengikutsertakan guru-guru dalam program pelatihan/ diklat serta mencipatakan iklim kerja yang kondusif disekolah.

Dengan bertambahnya wawasan keilmuan guru , diharapkan kinerja guru lebih meningkat lagi. Dan dengan terciptanya iklam kerja yang kondusif maka guru akakn merasa nyaman dalam bekerja dan terpacu untuk bekerja lebih giat lagi. Redding menyatakan bahwa iklim organisasi jauh lebih penting dari pada keterampilan atau teknik-teknik komunikasi semata dalam menciptakan suatu organisasi yang efektif.

\section{Pembahasan}

1. Kinerja Guru

Menurut (sukanto) kinerja pegawai adalah hasil dari pelaksanaan suatu pekerjaan yang bersifat fisik/mental maupu non fisik.non mental.

Menurut Mangkunegara (2000:164), kinerja pegawai adalah hasil kerja secara kulitas dan kuantitas yang dicapai oleh seorang pegawai dalam melaksanakan tuasgnya sesuai dengan tanggung jawab yang diberikan kepadanya.

Menurut KBBI (2005:770), kinerja pegawai adalah sesuatu yang dicapai, prestasi yang diperlihatkan, dan kemampuan kerja.

Menurut (sofiah, 2010) Kinerja dalam bahasa indonesia nya dikatakan sebagai prestasi kerja. Kinerja atau prestasi kerja adalah sebagai ungkapan kemampuan yang didasari oleh pengetahuan, sikap, keterampilan, dan motivasi dalam menghasilkan sesuatu. Faktor-faktor utama yang mempengaruhi kinerja adalah kemampuan dan kemauan.

Ukuran kinerja diterjemahkan kedalam perilaku yang mendasar yaitu: kualitas kerja, kuantitas kerja, pengetahuan tentang pekerjaan, pendapat atau pernyataan yang disampaikan, keputusan yang diambil, perencanaan kerja dan daerah organisasi kerja.

Kinerja dapat diartikan sebagai kemampuan kerja yang dilihat dari tingkat pencapaian atau penyelesaian tugas yang sudah menjadi tanggung jawab nya, apakah sudah sesuai 
dengan standar dari beidang pekerjaan nya tersebut. Standar tersebut merupakan acuan bagi guru untuk menyelesaikan tugasnya.

Ukuran kinerja guru dapat dlihat dari rasa tanggung jawab nya dalam menjalankan amanah, profesi yang menjadi tugasnya. Dapat dilihat juga dari kepatuhan dan loyalitasnya dalam mekajalankan tugas keguruannnya didalam kelas dan tugas kependidikannya d liar kelas.

Menurut Sahretin dalam Kusmianto (1997:47) standar kinerja guru itu berkaitan dengan kuliats guru dalam menjalankan tugasnya yakni:

a Bekerja dengan siswa secara individual

b Persiapan dan perencanaan pembelajaran

c Pemberdayaan media belajar

d Melibatkan siswa dalam berbagai pengalaman belajar

e Kepemimpinan yang aktif oleh guru

Kinerja guru dapat dikukur berdasarkan spesifikasi/ kriteria kompetensi yang hatus dimilki oleh setiap guru. Kinerja guru disini maksudnya yaitu nerkaitan dengan wujud perilaku yaitu kegiatan guru dalam proses pembelajaran yakni, bagaiman seorang guru itu dalam merencanakan pembelajaran, melaksanakan kegiatan pembelajaran, dan menilai hasil belejar peserta didiknya.

Menurut Mangkunegara ada 4 ukuran sasaran untuk mengukur tingkat prestasi kinerja yaitu:

a Kulitas.

Yaitu seberapa baiknya seorang karyawan mengerjakan apa yang seharusnya dikerjakannya.

b Kuantitas

Yaitu seberapa lama / kecepatan seorang pegawai dalam melaksanakan tugasnya dalam satu hari 
c Kehandalan

Yaitu seberapa jauh kemampuan seorang pegawai mampu melakukan pekerjaannya dengan akurat dan tidak ada kesalahan

d Sikap

Yaitu kemampuan seorang individu untuk dapat melaksanakan pekerjaan yang sedang dilakukannya. Aspek-aspek psikoogi yangtermasuk kedalamnya yaitu:

a) Daya tahan kerja

b) Kecepatan kerja

c) Sistematika kerja

2. Pendidikan dan Pelatihan

Pendidikan atau pelatihan adalah suatu proses yang menghasilkan perubahan perilaku yang menjadi sasaran diklat.perubahan perilaku disini maksudnya itu adalah berbentuk peningkatan mutu kemampuan.

Menurut Hardjanto(2012:69), pendidikan adalah berhungan dengan peningkatan umum dan pemahaman terhadap lingkungan kehidupan manusia secara menyeluruh dan proses pengembangan pengetahuan, kecakapan/keterampilan, pikiran,watak,karakter dan sebaginya.

Menurut Undang-Undang No.2 tahun 1989, pendidikan adalah usaha sadar untuk memprersiapkan peserta didik melalui kegiatan bimbingan, pengajaran, dan latihan bagi peranannya dimasa yang akan datang.

Jadi Pendidikan diartikan sebagai usaha sadar yang sistematis dalam mengembangkan potensi manusai secara optimal, baik itu berupa pola pikir maupun sikap dan perilaku yang ada didalam diri manusia tersebut.

Menurut Nitisemito ( 1994:82) pelatiahn adalah suatu kegiatan ari perusahaan yang bermaksud untuk dapat memeperbaiki dan mengembangkan sikap, tingkah laku, keterampilan dan pengetahuan dari para karyawan yang sesuaai dengan keinginan perusahaan yang bersangkutan.

Simamora (1997:256), juga mengunkapkan pelatihan adalah proses sistematik perubahan perilaku para karyawan dalam suatu arah guna meningkatkan tujuan-tujuan organisasional. 
Menurut Edwin B.Flippo dalam Hasibuan (2000:70), pelatihan/training adalah merupakan suatu usaha peningkatan pengetahuan dan keahlian seorang pegawai untuk mengerjakan suatu pekerjaan tertentu.

Menurut pasal 1 ayat 9 Undang-undang No.13 tahun 2003, pelatihan adalah keseluruhan kegiatan memberi, memperoleh, meningkatkan serta mengembangkan kompetensi,kerja, produktivitas, disiplin,sikap, dan etos kerja pada tingkat keterampilan dan keahlian tertentu sesuai dengan jenjang dan kualifikasi jabatan dan pekerjaan.

Dapat disimpulkan bahwa pelatihan yaitu sebagai suatu proses bersistem yang didalamnya ada suatu kegiata yang dimaksudkan untuk pengembangan serta perbaikan kinerja pesertanya guna meningkatkan tujuan-tujuan organisasional.

Diklat memiliki beberapa karakteristik yaitu:

a pelatihan dan pendidikan sama-sama membuat seseorang menjadi belajar,

b adanya transfer ilmu, pengetahuan, keterampilan, dan informasi dari sumber kepada pelajar, ,

c memerlukan sumber belajar, sarana prasaran yang mendukung,

d bersifat dinamis, tidak statis,

e memiliki tujuan akhir untuk meningkatkan kualitas diri orang tersebut.

Tujuan diklat menurut PP RI No.101 tahun 2000 pasal 2 yaitu:

a meningkatkan pengetahuan, keahlian, keterampilan, dan sikap untuk dapat melaksanakan tugs jabatan secara profesional dengan dilandasi kepribadian serta etika PNS sesuai dengan kebutuhan instansi

b mencipatakan aparatur yang mampu berperan sebagai pembaharu dan perekat persatuan dan kesatuan bangsa

c menetapkan sikap dan semangat pengabdian yang berorientasi pada pelayanan, pengayoman, dan pemberdayaan masyarakat

d menciptakan kesamaan visi dan dinamika pola pikir dalam melaksanakan tugas pemerintaha umum dan pembangunan demi terwujudnya kepemerintahan yang baik 
Tujuan diklat menurut Simamora dalam ( Sulistiyani dan Rosidah, 2003:174) yaitu:

a memperbaiki kinerja

b memutakhirkan keahlian para pegawai sejalan dengan kemajuan teknologi

c membantu memecahkan persoalan operasional

d mengorientasikan pegawai terhadap organisasi

e memenuhi kebutuhan-kebutuhan pertumbuhan pribadi

f meningkatkan efisiensi dan efektifitas kerja pegawai dalam mencapai sasaransasaran yang telah ditetapkan.

Wursanto ( 1989:60) mengemukakan manfaat pendidikan dan pelatihan ini bagi guru yaitu:

a pendidikan dan pelatihan meningkatkan stabilitas pegawai

b pendidikan dan pelatihan dapat memperbaiki cara kerja pegawai

c dengan adanya diklat pegawai dapat berkembang dengan cepat

d dengan adanya diklat dimaksudkan pegawai diberi kepempatan untuk mengembangkan diri

Untuk menentukan berhasil tidaknya program diklat maka perlu diadakan kegiatan evaluasi. Berikut manfaat diadakannya evaluasi menurut Siswanto (2003:220-221) sebagai beriku:

a untuk megetahui tingkat kemajuan yang telah dicapai oleh peserta diklat dalm suatu periode proses belajar mengajar tertentu

b untuk mengetahui posisi atau kedudukan peserta dalam kelompoknnya

c untuk mengetahui tingkat usaha yang telah dilakukan para peserta dalm kegiatan diklat

d untuk mengetahui efisiesni metode diklat yang digunakan

- Hubungan pendidikan dengan Kinerja pegawai

Pendidikan merupakan faktor yang akan mencerminkan kemampuan seseorang untuk dapat menyelesaikan suatu pekerjaan. Dengan menempuh pendidikan menyebabkan 
seorang pegawai memiliki pengetahuan sehingga cakap dalam melaksanaka tugasnya dengan baik.

- Hubungan Pelatihan dengan Kinerja pegawai

Pelatihan merupakan suatu usaha peningkatan pengetahuan dan keahlian seorang pegawai untuk mengerjakan suatu pekerjaan tertentu. Dengan adanya peningkatan keahlian, pengetahuan, wawasan dan sikap karyawan terhadap tugas-tugasnya melalui program pelatihan yang sudah dilaksanakan maka akan dapat meningkatan kinerja pegawai organisasi tersebut.

- Hubungan pendidikan dan pelatihan dengan kinerja pegawai Antara pendidikan dan pelatihan itu saling mempengaruhi. Sudiro (2009:8) mengatakan bahwa salah satu cara untuk menigkatkan kulaitas sumber daya manusia organisasi ialah melalui program pendidikan dan pelatihan yang dilaksanakan terencana dan sistematik. Pentingnya pendidikan dan pelaihan ini dalam oragnisasi adalah perbaikan kinerja pegawai meliputi knowledge dan keterampilan yang mendukung serta pembentukan sikap setiap para pegawai sesuai yang diinginkan oleh organisasi.

Menurut (aswardi, 2018) Salah satu metode yang dapat dilakukan dalam pelatihan yaitu penelitian tidakan kelas. Menurut Hopkins (1993) dalam Nelitawati dan Aswardi (2017) penelitian tindakan kelas adalah upaya [erbaikan pelaksanaan praktek pendidikan oleh sekelopok guru dengan melakukan tindakan-tindakan dalam pembelajaran, berdasarkan refleksi mereka mengenai hasil dan tindakan-tindakan tersebut.

\section{Hakikat Iklim Kerja}

Menurut (sofiah, 2010) Davis (1982:104), mengemukakan bahwa iklim kerja adalah seperangkat ciri atau atribut yang dirasakan individu dan yang dipertimbangkan berdampak pada keinginan individu untuk berprestasi sebaik-baiknya.

Menurut (m.saleh, 2015) Forehand dan Gilmers ( Toulson \& Smith, 2011). Megatakan bahwa iklim organisasi adalah serangkaian deskripsi dari karakteristik organisasi yang bertahan dalam jangka waktu lama. Iklim ini membedakan satu organisasi dengan organisasi lain. 
Gibson,ddk ( 2010) memngatakan bahwa iklim organisasi adalah sifat lingkungan kerja atau lingkungan psikologis dalam organisasi yang dirasakan oleh para pekerja atau anggota organisasi dan dianggap dapat mempengaruhi sikap dan perilaku pekerja terhadap pekerjaanya.

Iklim organisasi akan mennetukan apakah seseorang dapat melaksnakan tuags dan tanggung jawab sesuai prosedure atau tidak. Iklim organisasi yang bersifat kekeluargaan, nyaman dan menyenangkan akan membuat para karyawan lebih giat lagi dalam bekerja dan begitu juga sebaliknya.

\section{Kesimpulan}

Kesimpulan yang dapat penulias ambil yaitu sebagai berikut:

a Mengenai pengaruh diklat kepemimpinan guru terhadap kinerja guru. Makin banyak yang mengikuti diklat kepemimpinan guru maka akan mengakibatkan naiknya kinerja guru.

b Mengenai pengaruh iklim kerja terhadap kinerja guru. Semakin baik iklim kerja maka akan mengakibatkan naiknya kinerja guru

c Mengenai pengaruh stimulan diklat kepemimpinan guru. Semakin banyak guru yang mengikuti diklat kepemimpinan guru dan membaiknya iklim kerja, maka akan mengakibatkan naiknya kinerja guru

\section{Daftar Pustaka}

Aswardi, N. D. (2018). Efektivitas Pelatihan Metode Penelitian Tindakan Kelas Bagi Guru Sd Di Kecamatan Padang Timur Kota Padang. Jurnal Aplikasi Iptek Indonesia , 1-5.

M.Saleh, L. (2015). Pengaruh Iklim Organisasi Dan Komitmen Organisasi Terhadap Pembentukan Organizational Citizenship Behavior (Ocb) Karyawan Dalam Rangka Peningkatan Kinerja. E-Jurnal Apresiasi Ekonomi , 3 (2).

Sofiah, H. D. (2010). Pengaruh Pendidikan Latihan (Diklat)Kepemimpinan Guru Dan Iklim Kerja Terhadap Kinerja Guru Sekolah Dasar Se Kecamata Babakancikao Kabupaten Purwakarta. Jurnal Peneliatan Pendidikan , 11 (2), 90-105.

Sukanto, P. E. Pengaruh Pendidikan Dan Pelatihan Terhadap Kinerja Pegawai (Studi Pada Badan Kepegawaian Daerah Kota Malang). Jurnal Admnistrasi Public , 2 (1), 161-121. 
